\title{
Relationship between Information System Components, Trust, and User Satisfaction in terms of Using Green Processes and Technology
}

\author{
Mahmood Zohoori \\ Master Of Environmental Management \\ UPM \\ Birjand, Iran
}

\author{
Samaneh Falaki \\ Master of Environmental Assessment and Land \\ Use Planning \\ University of Birjand \\ Birjand, Iran
}

\begin{abstract}
Nowadays there are great concerns about environmental pollution which bring attentions on the use of green products and processes. Many researches have been conducted and are being conducted in various industries with different scopes in this term. However, the crucial point is whether green technology and processes are able to adapt in various industries. This research with using quantitative approach attempts to highlights effective variables on trust in green technology and processes, and also impact of trust on user satisfaction at one of the Malaysian university. Thus, considering to Information system success model (IS success model) and previous researches that have been conducted by scholars, this research have chosen Green information quality and Green system quality which are able to influence trust. According to the results obtained from collecting of 150 data from university staff including academic and official staff via distribution of questionnaire, showed that Green system quality, and Green information quality have significant and positive relation on trust. In addition, the impact of Green system quality and Green information quality on trust is significant and positive. On the other hand, the relationship between Trust and User satisfaction is positive and significant; furthermore, trust has a significant and positive impact on user satisfaction.
\end{abstract}

Keywords: Green environment, System quality, Information quality, Trust, User satisfaction.

\section{INTRODUCTION}

Nowadays industries consume more energy than necessary, and it causes more pollution. That is why it is important to establish a management system based on green processes and products to reduce the pollutions. Furthermore, the opportunities are provided in green technology. All governments and companies look for ways to reduce waste, because earth's environment today is not in a good state in the term of pollution such as: forest disappearing, water contamination, global warming, and etc that are the major problems for environment. On the other hand, in roofed environment like offices with mechanical ventilation, but without recirculation, devices like computers can cause sensory pollution loads (Al-Ali et al., 2010). In fact, the personal computers (PCs) are found as a strong indoor pollution sources. Besides sensory pollution load of each single PC is 3.4 Olfactus (olf) even when they are serviced for every three months (Bakó-Biró et al., 2004).

Chemical analysis detects there is pollutants emitted by PCs. The most significant chemicals include phenol, toluene, 2ethylhexanol, formaldehyde, and styrene (Al-Ali et al., 2010). So these types of pollutions have an important negative impact on the air quality, not only in offices but also in many spaces including homes. Furthermore, (National Public Radio) NPR reports by Chris Arnold in 2004 from Environmental Protection Agency officials say: Computers and computer monitors in the United States are responsible for the unnecessary production of millions of tons of greenhouse gases every year (Ravali et al., 2011).

With the entire world talking about going green, everyone can chip-in his/her bit for the environment and save money and energy. Generally, PCs and other IT equipment consume a lot of electricity and have high carbon emission levels. Accordingly, if there is a potential to enhance the quality of systems used in various industries, there will be a possibility to cut down the emissions. For instance use of Green PCs that are especially designed to minimize power consumption. Moreover, Green PCs draw less power than normal PCs and support sleep modes. A Green PC is a computer that has low power consumption and is environment friendly. It supports sleep modes in which the computer cuts down the power of unnecessary components when it is inactive. Configuring and assembling a Green PC is an easy task. 
Many computer components are easy on the environment, save energy and thus, help cut costs. Saving the environment and cutting down on energy consumption has become the need of the hour. With the help of Green PCs, it has now become easier to be environmentally aware without compromising on technological advancements. A Green PC is assembled with environment friendly components. It comes with a number of options such as the option to dim the monitor when it hasn't been in use for some time, the components like CPU, monitor, etc. don't give off high degree of radiation, the components are recyclable, etc. Furthermore, other components like Processors, Motherboards, Monitors, and Hard Drives have come out with new products that consume less power than the earlier manufactured processors and are better or equal in performance.

Besides, if quality of information rises alongside of quality of system, it will be easier to use the systems like PCs. Because in fact information quality is the desirable characteristics of the system outputs. For example: relevance, understandability, accuracy, conciseness, completeness, understandability, currency, timeliness, and usability are all characteristics of a system with high degree of information. On the other hand, capabilities of an information system lead to increase in system usage (Pitt et al., 1995), (Petter, S et al., 2008).

According to the results obtained from past researches by different experts it can be said that user satisfaction can be influenced by some main elements and as a result the performance of individuals remains as a gap related to green behavior. A new framework was developed in this study that conncets information quality and the system quality to Trust and also user satisfaction. Another gap refers to consider green product and porcess for each variable.

\section{Literature review}

\subsection{Information System Success Model}

The term IS or information system success is a popular term to measure the information system (Lin et al., 2006). A large number of studies in MIS or management of information system scholarship have developed IS model of success (Delone et al., 2003; Seddon et al, 1997; Pitt et al. 1995).

Approximately 180 papers about evaluation of IT investment elements have been reviewd that they were published during the 70s and 80s. consistent with the statements of (DeLone et al., 1992) an IS is model have been presented with six variables about IS success including information quality, system quality, system usage, user satisfaction, organizational impact and individual impact.

This model joins the comprehensive dependent factors applied by IS experts but on the other hand it also obtained some criticism. First of all, the usage of IS in the model that has been presented by Mclean and Delone has a lot of interpretations that needs to be examined. It is also mentioned that the IS usage plays a role which is controversial and problematic in the success of modeling system.

In second place, due to the fact that satisfaction of users demonstrates the individual influence of IS in a firm context, therefore it is not essential to investigate on a cause direction from satisfaction of users to individual influence. Finally, the last point that is very necessary is that this model does not describe the relation of individual influence and user satisfaction in a transparent way (Edward et al., 2005). The developed definitions for each of these factors are as follow:

1. System quality: measures of the information processing systemitself

2. Information quality: measures of information system output

3. (Information) use: recipient consumption of the output of an information system

4. User satisfaction: recipient response to the use of the output of aninformation system

5. Individual impact: the effect of information on the behavior of the recipient

6. Organizational impact: the effect of information on organizational Performance (Fig. 2.2).

S-K. Lee, J-H, Yu / Automation in construction 25 (2012) 82-93

Figure 1: Delon and Mclean IS success model (1992)

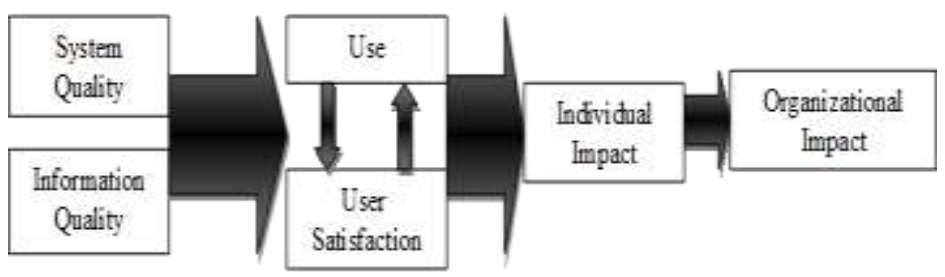

In 1994 Kiew and Seddon tested a modified version of the model which was made by Mclean and DeLone in 1992 that had the three significant differences as follows: 
(a) the usage was replaced by usefullness, (b) a factor crucial for the system was added in order to assist defining the differences in the perception of users related to user satisfaction and usefulness. (c) the casuality that exist among users and user satisfaction was changed by a casuality which was one way. The outcomes that were empirical developed some support for according to model of Mclean and DeLone in 1992. In 1997 Seddon stated a model of IS success in which the influence of society was added as a value of net of the IS (Figure 2.3).

Figure 2: The success model developed by Kiew and Seddon in 1994 and the success model of Seddon in 1997.

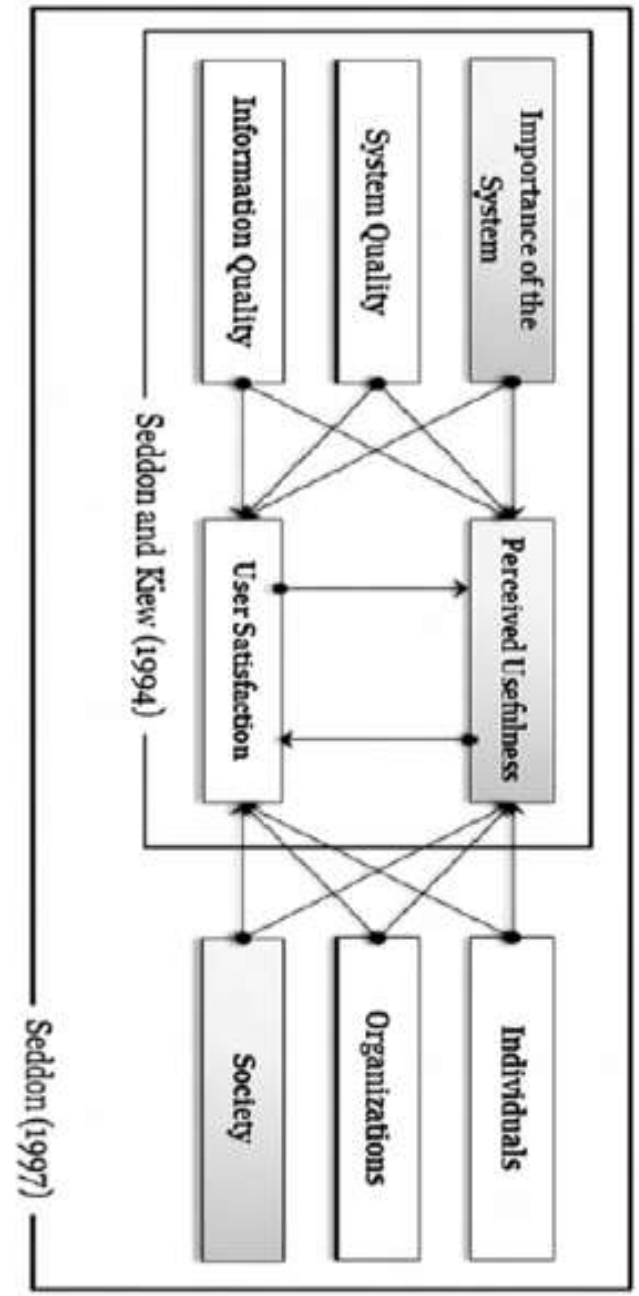

According to the success model of IS by Pitt in 1995 a service quality was addedd as an element of quality for the model of McLean and DeLone in 1992. For evaluation of service quality the measure tools are shaped from the modified SERVQUAL that were presented by Parasuraman in 1998 and after that the validity was tested (Figure 2.4).

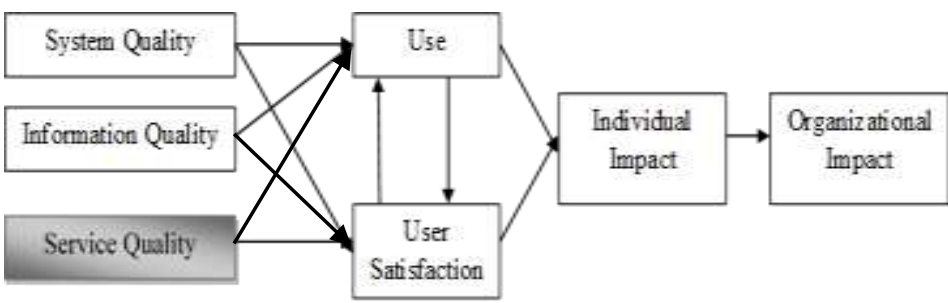

A success model was matured by Myers in 1997 and it was an extension of the McLean and Delone model in 1992 as well as Pitt's model back in 1995. This new model is not similar to the past models. The difference exists as follow: (a) the service quality was added, (b) a workgroup was added to assume the external and organizational context related to the approach of contingency (Figure 2.5).

Figure 4: Myers, Kuppleman, and Prybuton (1997)

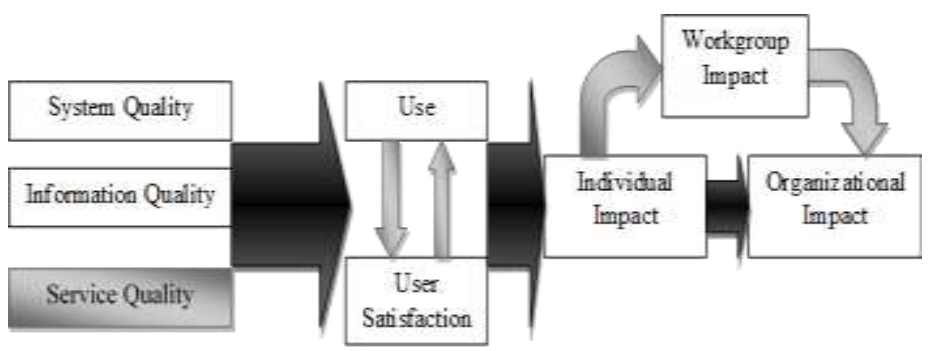

After over a decade past, McLean and Delone provided a model in 2003 that was updated and it disclosed the other researcher's critisim as well as the situation of that time. When the concept of service was added to information technology, the number of IS success elements were increased by means of using internet as well; moreover, it accelarated to seven and contained quality of service alongside with the interrelation and the correlation of them that were analyzed

Figure 5: Delone and Mclean IS success model (2003)

(Figure 2.6).
Figure 3: Pitt, Watson, And Kawan success model WWI (1995) 

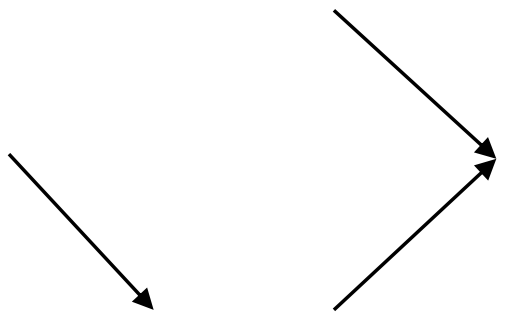

According to the results from previous researches many empirical studies support the left side of the model by McLean and DeLone which states that information quality, system quality and as well as service quality lead to user satisfaction and system usage. It was clarified that the manner and attitude can be influenced by quality in the context of IS. But there still exist some arguments about information system success construct.

This construct is different in accordance with the domain. The success model of IS in a lot of various industries have been used such as construction, and the experts that tried to set up and apply a success model of IS that started to appear and some of them have been conducted. The studies related to this topic of construction contain the fillowing aspects. (a) based on the model presented by McLean and DeLone they attempted to determine the factors of the success or the fault of the ERP system introduction that are utilized significantly in enterprise construction with the aim of evaluation, plan and project conduction for setting up and introducing the Enterprise Resource Planning (ERP) in the enterprise.

In this study the elements of success for the ERP system are classified in two separated groups. The first one is variables that are related to users like job relevance, output, result, image, system reliability and compatibility. The second group is variables that are related to the project which contain function, internal support and the support of consultant.

It can be concluded that the degree of completion for this research is high; furthermore, it offers a model of success to build the ERP system by a huge collection of data process as well as the data analysis. On the other hand, it should be mentioned that the recommended model has some restrictions for application for other types of IS due to the fact that it was described by concentration on ERP systems. (b) The elements related to attitude and behavior of end users were analyzed by EDM which is the management and engineering system which is for projects that have a large scale construction (Hjelt et al., 2007). The study provided a survey in which the elements that affect the Electronic Document Management (EDM) system acceptance will be drawn for a project that is constructive.

Based on these elements, the IS success model that was improved by McLean and DeLone mentioned that the function where an end user agrees with an EDM system in a project that is constructive. (c) Related to the above researches (Raymond et al., 2008) offered a model of success for project management information system or PMIS in accordance with the IS model of success and the rest of the theories. Based on this study the important elements that influence the success of PMIS are the information quality of PMIS and quality of PMIS.

To assess the quality of PMIS, it was decided to use eight items which are response time, accessibility, ease of use, flexibility, learning ease, querying ease, multi project capability and system integrartion. there are six factors for estimation of information quality of PMIS which are relevance, availibility, precision, reliability, security and comprehensiveness. However, as the authors declared the biggest flaw in this research is the fact that the model was measured by a small sample size which has been about 39 inividuals. The most related investigations provided a success model of IS based on the model of McLean and DeLone.

The goal of this research is recommending a model of IS success that is developed according to the two available models. Therefore, the recommended IS model of this study will depend to green products and services usage in industry of education.

\subsection{Green Environment in Malaysia}

The application of green products is same to green purchase and the reason is because the goal for both of them is the similar as the other one. Green purchasing can be expected as a crucial tool for replacement of environment; in adittion, the friendly usage as well as behavior of the production and consumption that provides a frequent green, and has many issues dependent to the environment like $\mathrm{CO}_{2}$ emission reduction.

The sectors all around the world including private, public or social were asked to purchase green to have a stable future (IGPN, 2009). Malaysia in terms of quality of marines and rivers have a normal level and range. From 146 rivers, 7 of them have been monitored, it means that around $4.8 \%$ of these rivers have been catagorized as polluted. This number of polluted rivers is more related to the amount of unhealthy rivers back in 2005 that was $10.3 \%$ or 15 rivers, but due to the fact that there was mist from July to October in 2006. While comparing with the past year the air had a fall down related to quality (Department of Environment, 2006). 
The amount of waste had an increase from 548,916,11 metric tons back in 2005 up to $1,103,457,06$ metric tons in the next year. From the different sources that bring a polluted air, three sources are from the vehichles, some of the industries like powerstations as well as operations which were negligent regarding an open burning in the country (Department of environment, 2006).

The main categories of waste produced in Malaysia which are hydrocarbon and oil, mineral sludge, dross, heavy metal sludge, gypsum and finally e-waste. Quantity of scheduled wastes generated by industry ranked from chemicals $(42.7 \%)$, electronic (21.6\%), automotive/workshop (17.2\%), metal (7.1\%), pharmaceutical (2.9\%) and other industries (Department of environment, 2006). It is anticipated if this trend of iresponsible behavior and consumption pattens continue, the environmental degradation would be aggravated. Therefore is shift towards green products and processes is required.

If the process of increase in economy and as well as using the patterns in a negligent way remains, there will be a vast damage on environment and ecosystem in Malaysia. The concept of green purchasing is new in Malaysia (MGPN, 2003). Until now, there have been little inquiry on doing the green purchasing for individuals in Malaysia. However, it can be mentioned that big organizations that are located in United States (US) or United Kingdom (UK) and other countries in Europe are developing some go green campaigns for advancing this concept.

On the other hand, the local industries do not care to this aspect; furthermore, they always wait to see what will happen (MGPN, 2003). The Green Purchasing Network Malaysia (MGPN) president during his speech in the first International Conference related to the green purchasing expressed that it is better that the government establish a condition to motivate firms to be the initiative and first leader for green buying performance.

\subsection{System Quality}

Generally, the quality of system compared to quality of information achieved a lower level of attention in the literature of IS. Additionally, the system quality factors are usually related to aspects related to ease of use and quality of service. For example (Bailey et al., 1983) contained several various system concepts related to services of IS in their investigations of satisfaction. (Raiet, 2002) expressed that system quality can be evaluated by operation of ease of use. These aspects are entirely related to each other but they are not similar.

An easy to use system can be also high quality so the easy usage of a system can be the result of quality of system. Furthermore, systems bundled with a high level of IT service may be considered to be of higher quality, making service quality a covariate to the quality of the system.
The above relations are the results of models of system success (Seddon et al, 1997). It brings a situation which expressed it is essential to make sure about the conceptual clarification for the distinction and specification of the aspects. In this case our offer is that there exist some dimensions which are unique that are the important parts of the system quality and they act separately from service elements or ease of use.

The degree in which quality of information has a relationship with output of the information system and the quality of system shows the needed system of information process for making the output. So the system quality dimensions demonstrate perception of users for interacting with the system during the time. In this case systems with more quality can be assumed as more easy to use and also have more usefulness in usage (Davis, 1989).

The interaction of system in an organizational environment happens with the aim of doing a defined task most of the time. Hence it will be better to assume the aspects of system quality by means of spectrum which has a ranking from system to task. Dimensions of a system can be described as the characteristics if a system which is essentially differs in various uses and can be measured independently from the task, application or the environment. The dimensions of a task can be defined as the elements of evaluation which are related to setting and task.

Our understanding of past studies demonstrates that there exist five necessary dimensions for the quality of system which are reliability, accessibility, response time, flexibility and finally integration by conducting more than 20 investigations for recognizing the system quality aspects.

\subsection{Information Quality}

The goal of developing information systems is bringing valuable information for decision making for the groups and individuals by management of sources, processing, storage and keeping. Their real value and benefits will be known while the provided information will be used in operations. (Swanson, 1974) expressed that quality of information that shows the degree of information system success is an important factor.

The concept of information quality demonstrates the output quality which is produced by information system (DeLone et al., 1992). This can be a report or an online screen. In 1987, Pazer and Ballou presented four dimensions for the quality of information including completeness, accuracy, timelines and consistency. There are also some aspects for data quality. (Nelson et al., 2005) decided to apply the accuracy, construct, currency, and completeness and information quality format. Based on these researchers format, an extra construct have been used in relation with layout presentation for the output of the information. 
The concept of accuracy usually expressed as the degree of correctness in stored information's mapping process for a proper state in the real context which the information demonstrates (Delone et al., 2003; Zmud, 1979; Nelson et al., 2005; Narasimhaiah et al., 2010; Fisher et al., 2001). When completeness mentioned, it is meant that the benefits and values of a defined variables have been recorded. It focuses on the fact that whether all values for all the factors have been recorded and kept. (Zmud, 1979; Nelson et al., 2005; Narasimhaiah et al., 2010; Fisher et al., 2001).

The term consistency demonstrates the data value has the same representation in all of the situations (Ballou et al., 1987; Pallant 2001, Hair et al. 1998; Nelson et al. 2005). On the other hand, currency means the extent in which there exists updated information and the degree of power of information to reveal the current situation that is reflected around us globally. Additionally, timeliness means that there will be no out of date value.

It is essential to have a data that is always available to influence the decision making and as a result, it can be changed in accordance with context and the person who makes decision. For instance a strategic developer might apply the information that is not new, but a production manager must have the latest updated data (Delone et al., 2003; Zmud, 1979; Strong et al., 1996). According to DeLone 2003, representative quality shows the format (Barki et al., 1985; Nelson et al., 2005). In fact when the word format is used, it means that the extent in which the presented information acts in a way which can be understood and explained for users, and also helps the task to be completed.

The relevance of the data describes the data application for a defined problem by a defined user. Related data can be used in a direct way to solve business problems (Ballou et al., 1987). Table 2.1, shows five main groups of information quality which are currency, format, dimension completeness and accuracy.

\begin{tabular}{|c|c|c|}
\hline Dimension & Definition & $\begin{array}{l}\text { Information } \\
\text { quality category }\end{array}$ \\
\hline Accuracy & $\begin{array}{l}\text { The degree in which } \\
\text { information is correct, } \\
\text { meaningful, believable, } \\
\text { and consistent. }\end{array}$ & Intrinsic \\
\hline Completeness & $\begin{array}{l}\text { The degree in which all } \\
\text { possible states relevant } \\
\text { to the user population } \\
\text { are represented in the } \\
\text { stored information. }\end{array}$ & $\begin{array}{l}\text { Extrinsic; } \\
\text { contextual }\end{array}$ \\
\hline Currency & $\begin{array}{l}\text { The degree to which } \\
\text { information is up-to- } \\
\text { date, the information } \\
\text { precisely reflects the } \\
\text { current state of the } \\
\text { world that it represents. }\end{array}$ & \\
\hline Format & $\begin{array}{l}\text { The degree to which is } \\
\text { presented in a manner } \\
\text { that is understandable } \\
\text { and interpretable to the } \\
\text { user and thus aids in the } \\
\text { completion of a task. }\end{array}$ & $\begin{array}{l}\text { Extrinsic; } \\
\text { representational }\end{array}$ \\
\hline
\end{tabular}

\subsection{User Satisfaction}

The positive effect of user satisfaction on performance of individuals was supported in past studies (Gatian et al., 1994; Guimaraes et al., 1997; Igbaria et al., 1997). For example the survey related to server/client system that was developed by (Guimaraes et al., 1997) it was found that the satisfaction of end users influences positively end user's job (the accuracy that is requested by job, feedback on job performance and skills required for the job). According to statement developed by (Igbaria et al., 1997) the satisfaction of users is considered as a factor which has the most powerful effect that is also direct on people's assumed impacts of performance, but is recognized a significant role for using the system for moderating the individual impact and the relation with user satisfaction.

Besides, other experts recommended that the degree of individual impact will alter by user satisfaction for example effectiveness of performance, decision, understanding the information, identification of problem and the individual productivity.

The main objective of (Hou, 2012) in his research was testing the framework for comprehension of the relation between system usage, EUCS or end user computing satisfaction and also individual performance. Data was collected from 330 end users in BI or business intelligent system in electronic industry of Taiwan that was used to measure the recommended relation in the framework by means of structural equation of the method of modeling. This model was received strong support by the result which has been collected. The results demonstrated that the usage of BI 
system as well as performance of individual can be enhanced by having more EUCS. (Figure 2.7).

Figure 5: Impact of user satisfaction on individual performance

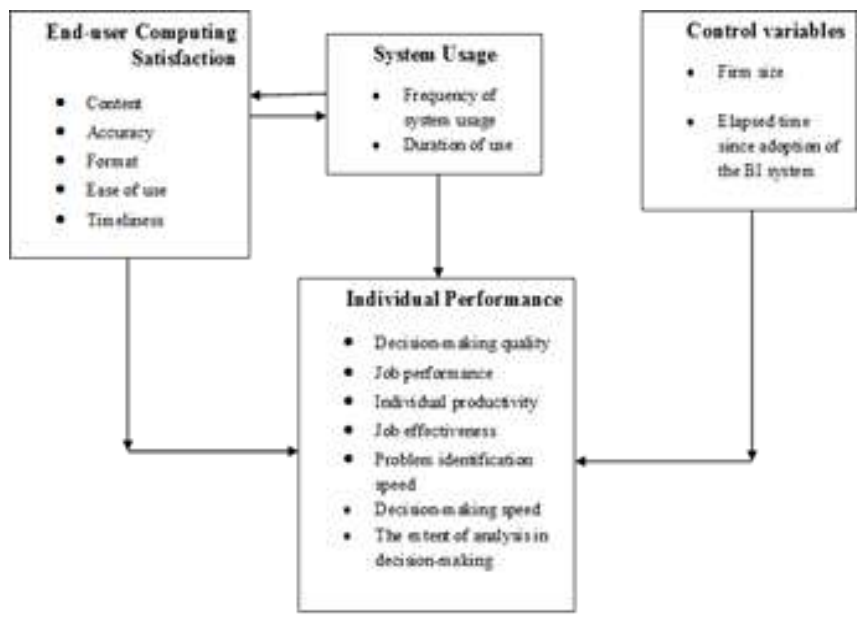

\subsection{Trust}

As Manafi et al. (2011) cited, Lee and Fung (1999) and Fukuyama (1995) trust is defined as the willingness and thoughts about relying on someone's goodness, strength and fairness. Of the internet in this regard could be a good example. Sloman \& Grandison conducted other research in 2000 , and described trust as the idea of one firm to do individually and dependently with a specific meaning. They defined trust based on behavioral and security issues, while popularity and reliability of trust suggested by Fukuyama.

\subsection{Trust and User Satisfaction}

User satisfaction is a popular measure of IS success, in which many standardized instruments have been improved and tested (Zviran et al., 2003; Doll et al., 2004). User satisfaction is an essential construct because it's related to other important variables, including systems analysis and design. Satisfaction has been used to evaluate IS success and effectiveness, the success in decision supports systems, office automation success and the utility of IS in decision making (Zviran et al., 2006). In web-based systems, specially, satisfaction can depend on multiple factors, such as content, navigation, information structure, user interface and web design.

Satisfaction greatly depends on performance from marketing perspective; however, product experience does not define overall satisfaction lonely (Anderson et al., 1993). Research has described that the expected performance level and knowledge achieved by outcomes that were not experienced are also important. In other words, when individuals measure outcomes, in fact they compare their experienced results with the results that might have occurred and chosen differently (Kahneman et al., 1986).

In a similar manner, development of trust has been described as the process setting expectations of another's behavior and then measuring whether those expectations have been confirmed (Garbarino et al., 1999).

Expectations can act as cognitive filtering devices by predisposing one individual to interpret another's behavior as consistent with original expectations. For instance, Holmes (1991) understood that trusting marriage partners block out or reinterpreted actions by their spouse positively that didn't match their trusting expectations. In this regard, when a consumer trusts an institution, it means there are expectations for satisfaction according to the institution's website that are likely to be confirmed. Beside as shown in Figure 2.8, user satisfaction extended to customer satisfaction and tested following framework in mobile banking industry (Lee and Chung, 2009).

Figure 6: Lee and Chung 2009

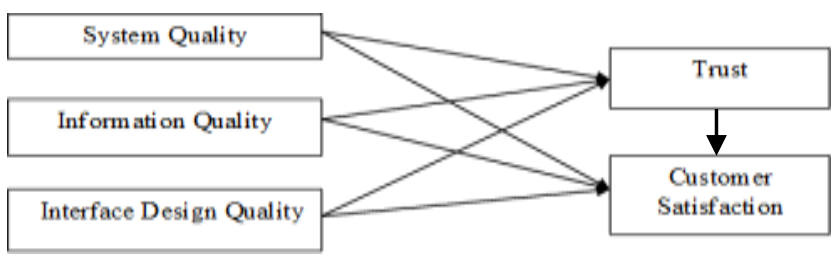

\subsection{Hypotheses development}

By reviewing and getting knowledge from previous studies and investigations, this current study recommends a framework. With no doubt all of the links in this framework are supported by the past studies (Figure 2.9).

Figure 7: Proposed Framework

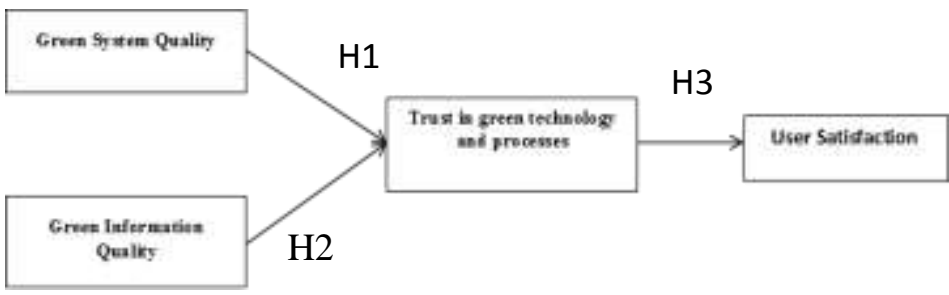

It is crucial to evaluate the impact of independent factors on dependent factors. It can be done after defining the theoretical model as well as independent factors. So there are five formulated hypotheses as the following statements:

H1: Trust is affected by system quality positively and significantly. 
H2: Trust is affected by information quality positively and significantly.

H3: user satisfaction is affected by trust positively and significantly.

\section{Method and results}

To test mentioned hypotheses, this research applied quantitative approach. In this regard, the questionnaire was adapted from prior research developed by Delone and Mclean (2003) and Lee and Chung (2009). It should be mentioned that all items of questionnaire were based 5-point Likert scale. The staffs who are working at University Putra Malaysia (UPM) are considered as the population of this study. They will be selected between the official members because they are more participating in internal process that is non paperless or paperless. Besides, the sample size was 150 . Table 2 shows the frequencies of demographic questions.

Table 2: Frequency of demographic questions

\begin{tabular}{|c|c|c|c|c|c|}
\hline & & Frequency & Percent & Valid Percent & $\begin{array}{c}\text { Cumulative } \\
\text { Percent }\end{array}$ \\
\hline \multicolumn{6}{|c|}{ Age } \\
\hline \multirow{5}{*}{ Valid } & less than 20 & 30 & 20.0 & 20.0 & 20.0 \\
\hline & $21-40$ & 54 & 36.0 & 36.0 & 56.0 \\
\hline & $41-50$ & 42 & 28.0 & 28.0 & 84.0 \\
\hline & more than 51 & 24 & 16.0 & 16.0 & 100.0 \\
\hline & Total & 150 & 100.0 & 100.0 & \\
\hline \multicolumn{6}{|c|}{ Gender } \\
\hline \multirow{3}{*}{ Valid } & Male & 84 & 56.0 & 56.0 & 56.0 \\
\hline & Female & 66 & 44.0 & 44.0 & 100.0 \\
\hline & Total & 150 & 100.0 & 100.0 & \\
\hline \multicolumn{6}{|c|}{ Educational level } \\
\hline \multirow{4}{*}{ Valid } & $\begin{array}{l}\text { high school and } \\
\text { Diploma }\end{array}$ & 45 & 30.0 & 30.0 & 30.0 \\
\hline & Bachelor & 81 & 54.0 & 54.0 & 84.0 \\
\hline & master or higher & 24 & 16.0 & 16.0 & 100.0 \\
\hline & Total & 150 & 100.0 & 100.0 & \\
\hline
\end{tabular}

Besides, Table 2 represents central indicators of each item of questionnaire. 
International Journal of Science and Engineering Applications

Volume 5 Issue 7, 2016, ISSN-2319-7560 (Online)

Table 3: Measure of the Construct and descriptive

\begin{tabular}{|c|c|c|c|c|}
\hline Constructs & Mean & $\begin{array}{l}\text { Standard } \\
\text { Deviation }\end{array}$ & Kurtosis & Skewness \\
\hline \multicolumn{5}{|l|}{ Green System Quality } \\
\hline $\begin{array}{l}\text { The green technologies (e.g. paperless process, faster PCs, latest } \\
\text { version of windows, disposable glass, etc.) can be applied in my } \\
\text { job. }\end{array}$ & 3.5533 & 1.27725 & -.698 & -.505 \\
\hline $\begin{array}{l}\text { The green technologies/products can be considered as reliable in } \\
\text { my job. }\end{array}$ & 3.6867 & 1.05000 & -.188 & -1.172 \\
\hline I have access to green products/processes any time I need. & 3.4067 & 1.14749 & -.497 & -.458 \\
\hline The green products and processes are usable in my job. & 3.6867 & 1.05000 & -.188 & -1.172 \\
\hline $\begin{array}{l}\text { Green technology facilitates my job as well as other technologies } \\
\text { are being used. }\end{array}$ & 3.5200 & 1.40813 & -.633 & -.882 \\
\hline \multicolumn{5}{|l|}{ Green Information Quality } \\
\hline $\begin{array}{l}\text { By using the green proceeding (online banking, e-filing of taxes, } \\
\text { etc.) can support all means of information and services. }\end{array}$ & 3.3200 & 1.15462 & -.546 & -.857 \\
\hline In green process, everything is more understandable. & 3.4067 & 1.14749 & -.497 & -.458 \\
\hline $\begin{array}{c}\text { The green services can connect internal and external } \\
\text { Networks }\end{array}$ & 3.0467 & 1.29706 & -.387 & -1.089 \\
\hline $\begin{array}{l}\text { I think the green services makes a company's activities as secure } \\
\text { as well as other working processes like bookkeeping, sales } \\
\text { tracking, etc. }\end{array}$ & 3.0733 & 1.25370 & -.161 & -1.192 \\
\hline \multicolumn{5}{|l|}{ Trust } \\
\hline $\begin{array}{l}\text { I really think by using green products at the university affects } \\
\text { positively the environment. }\end{array}$ & 3.4000 & 1.56728 & -.369 & -1.384 \\
\hline $\begin{array}{l}\text { I really think by using green processes at the university affects } \\
\text { positively the environment }\end{array}$ & 3.3000 & 1.00835 & -.036 & -1.247 \\
\hline Using the green technology enhances my effectiveness in my job. & 3.1000 & 1.30436 & -.463 & -1.033 \\
\hline $\begin{array}{l}\text { Using green technology (product and process) facilitates the } \\
\text { internal process towards a green environment. }\end{array}$ & 3.1000 & 1.22474 & -.193 & -1.222 \\
\hline \multicolumn{5}{|l|}{ User Satisfaction } \\
\hline The green technology provides the precise information I need. & 3.3800 & 1.51356 & -.373 & -1.265 \\
\hline $\begin{array}{l}\text { The information content provided by the green technology meets } \\
\text { my need. }\end{array}$ & 3.4133 & 1.02444 & -.104 & -1.180 \\
\hline $\begin{array}{l}\text { The green technology provides reports that seem to be just about } \\
\text { exactly what I need. }\end{array}$ & 3.1000 & 1.30436 & -.463 & -1.033 \\
\hline The green technology provides sufficient information. & 3.2533 & 1.14802 & -.430 & -.943 \\
\hline Using green process/technology is pleasant for me. & 3.2800 & 1.26978 & -.243 & -.825 \\
\hline
\end{tabular}


The results of reliability test shows all values more than .07 . It means that all of the variables have acceptable internal consistencies (Nunally, 1978).

Table 3 shows the results of Pearson correlation test. It can be sure that the connection and relationship among each two elements is positive because all of the p-values are below 0.05 . Also, all of the correlations are seen as positive that shows the relationship is positive. From the information quality and system quality, the maximum correlation related to information quality (.742). Besides, the relationship between trust and user satisfaction is positive and significant because p-value is zero and estimated correlation is .794 .

Table 3: Correlations

\begin{tabular}{|c|c|c|c|c|c|}
\hline & & System & $\begin{array}{c}\text { Inform } \\
\text { ation } \\
\text { Qualit } \\
\mathrm{y}\end{array}$ & Trust & $\begin{array}{c}\text { User } \\
\text { Satisfa } \\
\text { ction }\end{array}$ \\
\hline System Quality & $\begin{array}{l}\text { Pearson Correlation } \\
\text { Sig. (2-tailed) }\end{array}$ & 1 & $\begin{array}{r}.795^{* *} \\
.000\end{array}$ & $\begin{array}{r}.615^{* *} \\
.000\end{array}$ & $\begin{array}{r}.464^{* * *} \\
.000\end{array}$ \\
\hline $\begin{array}{l}\text { Information } \\
\text { Quality }\end{array}$ & $\begin{array}{l}\text { Pearson Correlation } \\
\text { Sig. (2-tailed) }\end{array}$ & $\begin{array}{r}.795^{* *} \\
.000 \\
\end{array}$ & 1 & $\begin{array}{r}.742^{* *} \\
.000 \\
\end{array}$ & $\begin{array}{r}.526^{* *} \\
.000 \\
\end{array}$ \\
\hline Trust & $\begin{array}{l}\text { Pearson Correlation } \\
\text { Sig. (2-tailed) }\end{array}$ & $\begin{array}{r}.615^{* *} \\
.000 \\
\end{array}$ & $\begin{array}{r}.742^{* *} \\
.000 \\
\end{array}$ & 1 & $\begin{array}{r}.794^{* *} \\
.000 \\
\end{array}$ \\
\hline User Satisfaction & $\begin{array}{l}\text { Pearson Correlation } \\
\text { Sig. (2-tailed) }\end{array}$ & $\begin{array}{r}.464^{* *} \\
.000\end{array}$ & $\begin{array}{r}.526^{* *} \\
.000\end{array}$ & $\begin{array}{r}.794^{* *} \\
.000\end{array}$ & 1 \\
\hline
\end{tabular}

Referring to the proposed framework of this research, two regression analysis were applied. The first regression analysis refers to the impact of information quality and system quality on trust. The second analysis measured the impact of trust on user satisfaction. According to the fist regression analysis' results, $\mathrm{R}$ square is equal to .553 . This shows the fact that $55.3 \%$ of variation related to trust can explained by information quality and system quality. By using the Analysis of Variance (ANOVA) table, at least one of the variables has significant impact on trust because the p-value is equal zero. Besides, there is no multi co-linearity between information quality and system quality because Variance Inflation Factor (VIF) column shows value less than 5. (Hair et al. 2010).

The system quality has a significant and positive effect on trust because p-value is .022 (less than .05). The estimated coefficient is .172 that explains the positive influence. So, for every unit increase in system quality, trust will go up .172 units. Hence, the first hypothesis is accepted by this study. The results obtained from this study is consistent with previous researches conducted by Delon and Mclean (1992), Vance et al., (2008), and Lee and Chung (2009).

The information quality also has a significant and positive effect on trust because p-value is zero (less than .05). The estimated coefficient is .798 that explains the positive influence. So, for every unit increase in information quality, trust will go up .798 units. Hence, the second hypothesis is accepted by this study. The results obtained from this study is consistent with previous research conducted by Delon and Mclean (1992; 2003), and Aberer et al., (2001). However, the final regression equation is as below:

Trust $=.403+.172$ (system quality) +798 (information quality)

In the second regression analysis, $\mathrm{R}$ square is equal to .631 . This shows the fact that $63.1 \%$ of variation related to user satisfaction can explained by Trust. By using the ANOVA table, the user satisfaction will be affected by the trust because the p-value that is 0.00 and less than 0.05 .

The trust significantly impacts on user satisfaction because pvalue is 0.00 . The estimated coefficient is .710 that explains the positive influence. For every unit increase in trust, user satisfaction will go up .710 units. So, the third hypothesis is supported by this study. The results obtained from this study is consistent with the previous researches conducted by famous scholars for instance Bouckaert et al., (2003), and Morris et al., (2002).

However, the final regression equation is as below:

User satisfaction $=\mathbf{. 9 9 4 + . 7 1 0}$ (Trust)

\section{Recommendation, Limitation, and Future Study}

According to results of this study, Green system quality, Green information quality have significant and positive impacts on Trust, in addition, Trust has a significant and positive impact on user satisfaction. Hence, every effort on planning, promotion, and improvement in System quality, Information quality will help to trust among university staff.

On the other hand, every effort on trust will lead to user satisfaction in the studied university. Therefore, from the mentioned practices, having a clear policy and rules for promotion of quality factors leads to trust thereby user satisfaction among staff.

The most important limitation for this study is data collection from participants because some of the university staff had a 
little familiarity with green technology and processes, for example, what kind of tasks can help to green environment at the university. On the other hand, tendency of some staff showed little willingness to participate, and also some of them thought that participation in this research may be contradictory with the policy of the university.

As suggestions for future researches, this study recommends that proposed framework used in this study is examined at other universities. Besides, researches similar to this study can be conducted in industries such as manufacturing or banking.

Furthermore, R-square in the first Multiple Regression analysis is .553 although this value is not very low, but it motivates that in future researches a new variable is identified according to literature review to help improve the framework used in this study.

Figure 8: Proposed Framework for futurestudy

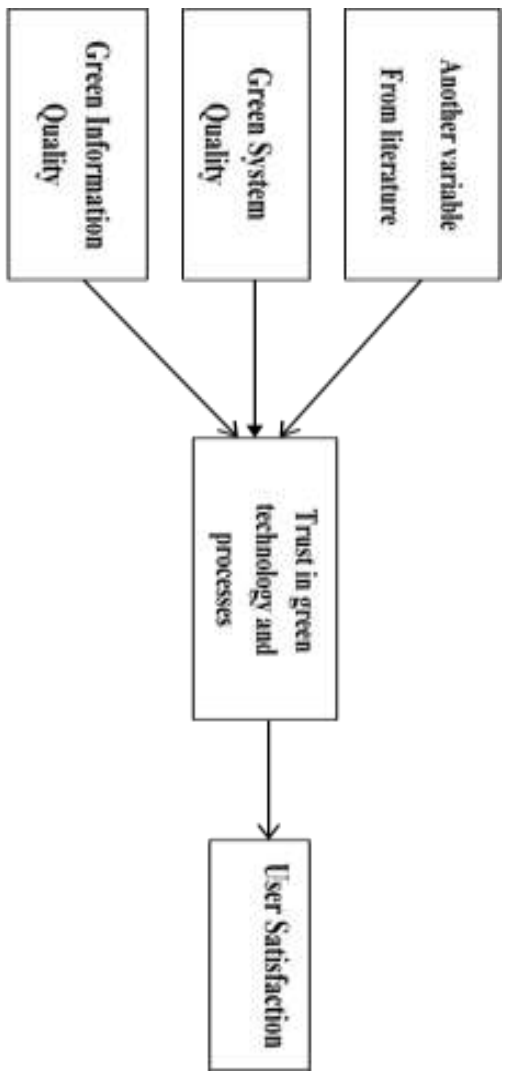

\section{References}

[1] Al-Ali, A. R., Imran Zualkernan, and Fadi Aloul. "A mobile GPRS-sensors array for air pollution monitoring." Sensors Journal, IEEE 10.10 (2010): 1666-1671.
[2] Anderson, Eugene W., and Mary W. Sullivan. "The antecedents and consequences of customer satisfaction for firms." Marketing science 12.2 (1993): 125-143.

[3] Aberer, K., \& Despotovic, Z. (2001, October). Managing trust in a peer-2-peer information system. In Proceedings of the tenth international conference on Information and knowledge management (pp. 310-317). ACM.

[4] Bako-Biro, Zsolt. Human perception, SBS symptoms and performance of office work during exposure to air polluted by building materials and personal computers. Diss. Department for Mechanical Engineering, Technical University of Denmark, 2004.

[5] Ballou, Donald P., and Harold L. Pazer. "Cost/quality tradeoffs for control procedures in information systems." Omega 15.6 (1987): 509-521.

[6] Bailey, James E., and Sammy W. Pearson. "Development of a tool for measuring and analyzing computer user satisfaction." Management science 29.5 (1983): 530-545.

[7] Ballou, Donald P., and Harold L. Pazer. "Cost/quality tradeoffs for control procedures in information systems." Omega 15.6 (1987): 509-521.

[8] Barki, Henri, and Sid L. Huff. "Change, attitude to change, and decision support system success." Information \& Management 9.5 (1985): 261-268.

[9] Bouckaert, G., \& Van de Walle, S. (2003). Comparing measures of citizen trust and user satisfaction as indicators of 'good governance': difficulties in linking trust and satisfaction indicators. International Review of Administrative Sciences, 69(3), 329-343.

[10] Davis, Fred D. "Perceived usefulness, perceived ease of use, and user acceptance of information technology." MIS quarterly (1989): 319-340.

[11] Delone, William H. "The DeLone and McLean model of information systems success: a ten-year 
update." Journal of management information systems 19.4 (2003): 9-30.

[12] DeLone, William H., and Ephraim R. McLean. "Information systems success: the quest for the dependent variable." Information systems research 3.1 (1992): 60-95.

[13] Department of Environment (2006).Malaysia Environmental Quality Report 2006.Ministry of Natural Resources and Environment Malaysia.

[14] Gagné, Marylène, and Edward L. Deci. "Self-determination theory and work motivation." Journal of Organizational behavior 26.4 (2005): 331-362.

[15] Fisher, Craig W., and Bruce R. Kingma. "Criticality of data quality as exemplified in two disasters." Information \& Management 39.2 (2001): 109-116.

[16] Fukuyama, Francis. Trust: The social virtues and the creation of prosperity. New York: Free Press, 1995.

[17] Fung, Raymond, and Matthew Lee. "EC-trust (trust in electronic commerce): exploring the antecedent factors." AMCIS 1999 Proceedings (1999): 179.

[18] Grandison, Tyrone, and Morris Sloman. "A survey of trust in internet applications." Communications Surveys \& Tutorials, IEEE 3.4 (2000): 2-16.

[19] Gatian, Amy W. "Is user satisfaction a valid measure of system effectiveness?" Information \& Management 26.3 (1994): 119-131.

[20] Guimaraes, Tor, and Magid Igbaria. "Client/server system success: exploring the human side." Decision Sciences 28.4 (1997): 851-876.
[21] Garbarino, Ellen, and Mark S. Johnson. "The different roles of satisfaction, trust, and commitment in customer relationships." The Journal of Marketing (1999): 70-87.

[22] Holmes, John G. "Trust and the appraisal process in close relationships." (1991).

[23] Hair, Joseph F., et al. "Black (1998), Multivariate data analysis." (1998): 577-664.

[24] Hou, Chung-Kuang. "Examining the effect of user satisfaction on system usage and individual performance with business intelligence systems: An empirical study of Taiwan's electronics industry." International Journal of Information Management 32.6 (2012): 560-573.

[25] Hjelt, Mathias, and Bo-Christer Björk. "End-user attitudes toward EDM use in construction project work: case study." Journal of computing in civil engineering 21.4 (2007): 289-300.

[26] Igbaria, Magid, and Margaret Tan. "The consequences of information technology acceptance on subsequent individual performance." Information \& Management32.3 (1997): 113-121.

[27] IGPN. (2009). Green Purchasing. Retrieved on October 9, 2009, from http://www.igpn.org/focus_on/igp_conf_2009/index .html

[28] Kahneman, Daniel, and Dale T. Miller. "Norm theory: Comparing reality to its alternatives." Psychological review 93.2 (1986): 136-153.

[29] Lee, Kun Chang, and Namho Chung. "Understanding factors affecting trust in and satisfaction with mobile banking in Korea: a modified DeLone and McLean's model perspective." Interacting with computers 21.5 (2009): 385-392. 
[30] Lin, Hsin-Hui, and Yi-Shun Wang. "An examination of the determinants of customer loyalty in mobile commerce contexts." Information \& management 43.3 (2006): 271-282.

[31] Lee, Seul-Ki, and Jung-Ho Yu. "Success model of project management information system in construction." Automation in construction 25 (2012): 82-93.

[32] Mahmoud Manafi, Roozbeh Hojabri, Ali Haj Aghapour, Mehrdad Salehi, Mohammad Reza Aghaei, Reza Ghesmi (2011), Trust in E-commerce, IJCRB, Vol.3, Issue 6, Pages 774-788

[33] Morris, S. A., Marshall, T. E., \& Rainer Jr, R. K. (2002). Impact of user satisfaction and trust on virtual team members. Information Resources Management Journal (IRMJ), 15(2), 22-30.

[34] MGPN. (2003, March). An Introductory Study on Green Purchasing Activities in Malaysia. Green Purchasing Network Malaysia: Kuala Lumpur.

[35] Narasimhaiah G., Toni, M.S.,Wong B., Organizational impact of system quality, information quality and service quality, The Journal of Strategic Information Systems 19 (3) (2010) 207-228.

[36] Nunnally, J. C. (1978). Psychometric theory (2nd ed.). New York: McGraw-Hill.

[37] Nelson, R. Ryan, Peter A. Todd, and Barbara H. Wixom. "Antecedents of information and system quality: an empirical examination within the context of data warehousing." Journal of Management Information Systems 21.4 (2005): 199-235.

[38] Pallant, J. "SPSS Survival Guide: A step by step guide to data analysis using SPSS." Open University Press: McGraw-Hill Education. Retrieved January 1 (2001): 2006.
[39] Petter, S., DeLone, W., \& McLean, E. (2008). Measuring information systems success: models, dimensions, measures, and interrelationships. European Journal of Information Systems, 17(3), 236-263.

[40] Pitt, Leyland F., Richard T. Watson, and C. Bruce Kavan. "Service quality: a measure of information systems effectiveness." MIS quarterly (1995): 173187

[41] Ravali, K., and P. Ashok Kumar. "TechnoPollution." Computer 1.4 (2011): 1416-1420.

[42] Raymond, Louis, and François Bergeron. "Project management information systems: An empirical study of their impact on project managers and project success." International Journal of Project Management 26.2 (2008): 213-220.

[43] Rai, A., Lang, S.S., Welker, R.B., 2002. Assessing the validity of is success models: an empirical test and theoretical analysis. Information System Research 13,50-69.

[44] Seddon, Peter B. "A respecification and extension of the DeLone and McLean model of IS success." Information systems research 8.3 (1997): 240-253.

[45] Swanson, E. Burton. "Management information systems: appreciation and involvement." Management Science 21.2 (1974): 178-188.

[46] Vance, A., Elie-Dit-Cosaque, C., \& Straub, D. W. (2008). Examining trust in information technology artifacts: the effects of system quality and culture. Journal of Management Information Systems, 24(4), 73-100.

[47] Zmud, Robert W. "Individual differences and MIS success: A review of the empirical literature." Management Science 25.10 (1979): 966-979. 
International Journal of Science and Engineering Applications

Volume 5 Issue 7, 2016, ISSN-2319-7560 (Online)

[48] Zviran, Moshe, and Zippy Erlich. "Measuring IS

user satisfaction: review and implications." Communications of the Association for Information Systems 12.1 (2003): 5.

[49] Zviran, Moshe, Chanan Glezer, and Itay Avni. "User satisfaction from commercial web sites: the effect of design and use." Information \& Management 43.2 (2006): 157-178. 